\title{
Discovery of the Youngest Toba Tuff in South Africa; Challenges of Extremely Low Abundance Cryptotephra
}

\author{
EUGENE SMITH $^{1}$, RACHEAL JOHNSEN ${ }^{1}$, MINGHUA \\ REN $^{1}$, JAYDE HIRNIAK ${ }^{2}$, ERICH FISHER ${ }^{2}$, CHRISTOPHER \\ CAMPISANO $^{2}$ AND CURTIS MAREAN ${ }^{2,3}$ \\ ${ }^{1}$ University of Nevada, Las Vegas \\ ${ }^{2}$ Arizona State University \\ ${ }^{3}$ Nelson Mandela University \\ Presenting Author: gene.smith@unlv.edu
}

The $74 \mathrm{ka}$ Youngest Toba Tuff (YTT) was discovered as cryptotephra in South African archaeological sites at Pinnacle Point (PP) 5-6N, Vleesbaai [1] and Klasies River on the Indian Ocean, and the Diepkloof Rock Shelter on the Atlantic coast nearly $750 \mathrm{~km}$ west of PP. The YTT eruption distributed tephra across eastern and southern Africa and provides a widespread isochron useful for dating archaeological deposits, testing age models, and precisely determining the timing of changes in human behavior. At PP, we demonstrated that the MIS 4-5 transition began just before the YTT eruption. Humans thrived both through the YTT event and the changing climate, and important changes in technology occurred just after the Toba eruption [1]. Controversy related to trapped charge age models at the Diepkloof rock shelter [2,3] were resolved by identifying YTT at a location in the stratigraphic section that confirmed the Jacobs et al. [2] model for the site, confirming that technological changes similar to those observed at PP occurred synchronously to those at Diepkloof, not substantially before as suggested by a prior published age model [3]. Processing samples with very low abundance cryptotephra, such as that found in South Africa, is a challenge and requires revision of standard laboratory techniques. Samples with high organic or clay content benefit by being treated with $10 \% \mathrm{HCl}$ and $3 \%$ hydrogen peroxide $\left(\mathrm{H}_{2} \mathrm{O}_{2}\right)$. This step does not degrade shard integrity or affect chemistry and is useful in separating shards from clay and organic particles allowing better recovery in heavy liquids. We also modified the heavy liquid density range from $1.95-2.55$ to $2.2-2.5 \mathrm{~g} / \mathrm{cm}^{3}$ to more effectively remove quartz and feldspar as well as biogenic silica. This density range captures shards ranging from rhyolite to dacite in composition.

[1] Smith, E. I. et al. Nature 555, 511, 2018

[2] Jacobs, Z. \& Roberts, R. G. Journal of Archaeological Science 63, 175-192, 2015.

[3] Tribolo, C. et al. Journal of Archaeological Science 40, 3401-3411 2013. 